\title{
Potensi Kriminal Cyber Crime pada Meme: Sebuah Kajian Linguistik Forensik
}

\author{
Sri Sugiarto ${ }^{1)}$, Rini Qurratulaini ${ }^{2)}$ \\ Sri.sugiarto90@gmail.com \\ Fakultas Keguruan dan Ilmu Pendidikan Universitas Samawa: Sumbawa: \\ Nusa Tenggara Barat ${ }^{12)}$
}

\begin{abstract}
Abstrak. Tulisan ini bertujuan untuk mendeskripsikan hasil analisis ekpresi bahasa pada meme yang berpotensi sebagai pelangaran kriminal cyber crime. Untuk mengganalisis potensi kriminal tersebut, digunakan metode penelitian kualitatif dengan pedekatan linguistik forensik. Data yang digunakan berupa bentuk lingual (kata,frasa,klausa) yang terdapat pada meme. Meme yang diambil adalah empat buah meme dengan tema isu-isu politik. Sumber data berupa media online (media masa). Data-data yang terkumpul kemudian dianalisis berdasarkan dimensi sintaksis, semantik, pragmatik, dan forensik. Hasil analisis menggunakan pendekatan linguistik forensik menunjukkan keempat meme berpotensi melanggar pelanggaran kriminal cyber crime. Potensi pelanggaran ini ditunjukkan dengan adanya muatan konten tindak tutur ilokusi persuasif dan ekspresif yang bersifat penghinaan. Bentuk penghinaan adanya penggunaan bentuk lingual seperti gila, idiot, presiden tidak berguna, dan penipu. Tujuan penghinaan secara jelas ditujukkan kepada penyerangan pribadi baik ditujukan kepada Jokowi maupun Prabowo. Keempat meme ini masih dapat diakeses secara bebas pada alamat situs masing-masing. Potensi pelanggaran terhadap keempat meme ini dapat memungkinkan pelaku penyebarnya terjerat UU ITE pasal 45 ayat 3 dan pasal 27 ayat 3. Selanjutnya pelanggaran penghinaan dapat juga ditinjau dengan KUHP Bab XVI pasal 310 sampai dengan pasal pasal 321 tentang pidana pelanggaran penghinaan.
\end{abstract}

Kata kunci: Kriminal, Cyber Crime, Linguistik Forensik

\section{Pendahuluan}

Dalam praktik kehidupan berdemokrasi, masyarakat Indonesia diberi kebebasan berpendapat yang dilindungi secara konstitusional. Hal ini tertuang dalam UUD 1945 pasal 28 E ayat 3. Kekebasan berpendapat tidak terlepas dengan penggunaan bahasa sebagai alat komunikasi. Kebebasan menyampaikan pendapat adalah keadaan bebas dari tekanan untuk mengemukakan gagasan atau buah pikiran, baik secara lisan maupun tertulis dan sebagainya secara bebas dan bertanggung jawab sesuai dengan ketentuan peraturan perundang-undangan yang berlaku.

Seiring dengan perkembangan IPTEKS, media komunikasi sudah mengalami perubahan yang luar biasa terutama pada bidang teknologi informasi. Dengan adanya perkembangan teknologi informasi, arus infromasi secara cepat tersebar di berbagai belahan dunia. Penyebaran informasi terjadi secara cepat didukung dengan adanya teknologi penyiran TV, dan internet.

Adanya perkembangan teknologi informasi ini semakin mempermudah masyarakat menyampaikan pendapat. Ditambah lagi dengan munculnya media komunikasi masa berbasis internet seperti wahts app, twiteer, facebook, instagram dan masih banyak media lainnya. Yang popular disebut dengan medsos (media sosial). Melalui berbagai medsos inilah 
masyarakat di seluruhan belahan dunia khususnya Indonesia dapat berekspresi menyapaikan pendapat dengan berbagai bentuk kreatifitas.

Tantangan yang muncul adanya medsos ini, salah satunya kerab kali masyarakat pengguna medsos (netizen) mengeluarkan pendapat dan informasi dilakukan secara tidak bijak. Banyak informasi yang disebar mengandung unsur SARA dan informasi bohong (hoaks). Yang menyebabkan penyebar informasi dapat terjerat hukum pelanggaran UU infromasi dan teknologi elektronik (UU ITE). Pada pasal 45 UU ITE salah satunya mengatur jenis pelanggaran pidana bekomunikasi dengan menggunakan media teknologi dan informasi.

Ceyber law (hukum cyber) merupakan hukum yang digunakan sebagai dasar atau pondasi hukum untuk pencegahan atau penegakan hukum di dunia cyber (dunia maya). Sekarang ini, kegiatan cyber meskipun bersifat virtual jika terbukuti adanya suatu tindakan kriminal tetap dianggap atau dikategorikan sebagai pelanggaran nyata sebagaimana pelanggaran konvensional lainya. Dilihat dari ruang lingkupnya, cyber law meliputi setiap aspek yang berhubungan dengan subyek hukum yang memanfaatkan teknologi internet yang dimulai pada saat mulai "on-line" dan seterusnya sampai saat memasuki dunia maya, (Tianotak, 2011).

Kasus kriminal cyber crime khususnya pelanggaran UU ITE akhir-akhir ini banyak sekali menjerat netizen dengan berbagai ragam bentuk palanggaran. Palangaran yang sering muncul, yakni penyebaran informasi yang memiliki muatan penghinaan, penyebaran nama baik, pengancaman, asusila, dan berita bohong (hoaks). Berdasarkan data yang diliris SAFEnet latar belakang profesi terlapor pelanggaran ITE data tahun 2018-juli 2018 sangat beragam. Kelompok masyarakat awam sebesar $29,4 \%$, aktivis $8,2 \%$, pelajar dan mahasiswa 6,5\%, guru dan dosen, 6,1\%, jurnalis 5,3\%, pejabat Negara 4,5\%, LSM 4,1\%, Pengusaha $2,9 \%$, Pengacara 2,9\%, Karyawan 2,9\%, Pengiat Budaya 2,4\%, Selebritas 2\%, tenaga medis $2 \%$, supir 1,6\%, mantan ASN 1,6\%, pemuka agama 1,2\%, satpam 0,8\%, aparat keamanan 0,4\%, dan anggota partai $0,4 \%$ https://tirto.id/jerat-uu-ite-banyak-dipakai-oleh-pejabatnegara-c7sk, diakes 2019.

Salah satu bentuk ekspresi penyampaian dapat yang sering digunakan adalah meme. Meme ini banyak kita temukan di akun netizen, seperti facebook, blog, twitter, wahts app, instgram dan media sosial lainya. Bauckhage (2011) yang menyatakan bahwa meme biasanya berkembang melalui komentar, imitasi, atau parodi, atau bahkan melalui berita di media lain. Meme ini juga dapat dikatan sebagai bentuk ekspresi (senang, sedih, marah) yang diungkapkan dalam bentuk tulisan. Saat ini, disertakan pada media visual misalnya gambar yang dianggap mewakili perasaan dan maksud tersebut. Dengan melihat batasan ini, tidak jarang konten meme yang banyak tersebar di media sosial mengandung ungkapan atau ekspresi berupa rasa senang, sedih, marah, dan kecewa terahadap suatu objek yang dilihat. Hasil penelitian Listyorini (2017) tema yang biasa dituangkan dalam meme, yakni tema sosial, politik, hukum, dan HAM. Sementara implikatur dari kontenya mengandung menyindir, menyarankan, dan menghibur.

Penggunaan meme sebagai bentuk ekspresi bahasa tidak menjadi persolaan. Yang menjadi penekanan persoalannya pada penelitian ini adalah konten atau pesan yang disampaikan mengandung unsur pelanggaran yang memungkinkan menjerat si pelaku 
pembuat dan atau penyebar akan terjerat pelanggaran hukum. Yang akhirnya dapat merugikan diri sendiri.

Untuk membuktikan adanya konten suatu pelanggaran terhadap muatan konten sebuah teks meme, penanganan kasus pelanggaran ITE sangat perlu menggandeng saksi ahli bahasa atau pakar bahasa. Keberadaan saksi ahali bahasa berperan sebagai pemberi keterangan atau penjelasan terhadap data atau fakta dilihat dengan menggunakan tinjauan linguistik.

Dalam penangan kasus-kasus kriminal cyber crime akhir-akhir ini di Indonesia sudah mulai menggait disiplin ilmu bahasa untuk menunjukkan bukti-bukti atau fakat-fakta analisis secara kebahasan yang menujukkan adanya tindakan kriminal terhadap suatu teks yang mengandung konten pelanggaran UU ITE. Kasus-kasus kriminal cyber crime masih banyak belum terselsaikan, serta kasus-kasus yang baru selalu muncul. Oleh karana itu, tulisan ini bertujuan untuk menganalisis ekpresi bahasa pada meme yang berpotensi masuk pada pelanggararan kriminal cyber crime.

Penerapan kajian linguistik dalam menangani kasus kriminal cyber crime dapat ditangani dengan pendekatan linguistik forensik. Apa itu linguistik forensik?. Lingusitik forensik merupakan kajian multidisipliner, yaitu ilmu linguistik dan ilmu forensik. Merujuk pendapat Subyantoro (2017) menyatakan bahwa lingusitik forensik merupakan kajian penarapan ilmu linguistik dan ilmu hukum. Selanjutnya, senada dengan Fatimah (2016) kajian ilmu linguistik forensik penerapan ilmu linguistik dalam mengkaji aspek-aspek tertenu dalam bidang hukum. Lebih lanjut Olsson (2008) linguistik forensik adalah hubungan antara bahasa, tindak kriminal, dan hukum yang di dalamnya termasuk penegak hukum, masalah hukum, perundang-undangan, perselisihan atau proses hukum, bahkan perselisihan yang berpotensi melibatkan beberapa pelanggaran hukum yang ditujukan untuk mendapatkan penyelesain hukum.

Perlu juga di sini disampaikan ruang lingkup kajian linguistik forensik. Dengan membandingkan pendapat dari Subyantoro (2019) membatasi ruang lingkup kajian lingusitik forensik (1) bahasa sebagai produk hukum, (2) bahasa dalam proses peradilan, (3) dan bahasa sebagai alat bukti. Sementara itu, Could hard dan Jhonson (2010) merincikan cakupan kajian lingusitik porensik meliputi adalah: (1) bahasa dari dokumen legal, (2) bahasa dari polisi dan penegak hukum, (3) interview dengan anak-anak dan saksi-saksi yang rentan dalam sistem hukum, (4) interaksi dalam ruang sidang, (5) bukti-bukti linguistik dan kesaksian ahli dalam persidangan, (6) kepengarangan dan plagiarisme, serta (7) fonetik forensik dan identifikasi penutur. Dalam penelitian, analisis bahasa sebagai alat bukti pelanggaran. Lebih lanjut, Subyantoro (2019) hal perlu diperhatikan bahwa analisis yang disampaikan linguistik forensik tidak sampai pada ranah psikologis seperti menganalisis karakter pada tulisan tangan seseorang. Selain itu, analisis linguistik forensik tidak sampai pada keputusan bersalah ataupun tidak bersalah dalam proses persidangan, tetapi hanya sampai pada penentuan status dan peran keterlibatan setiap pihak dalam sebuah kasus yang melibatkan penggunaan bahasa.

Pembagian sub disiplin linguistik mikro deksriptif dapat dimanfaatkan dalam kajian lingustik forensik. Linguistik mikro deksriptif meliputi fonologi, morfologi, sintaksis, dan semantik, semiotik, pragmatik, dan analisis wacana. Senada dengan Subyantoro (2019) aspek-aspek linguistik yang digunakan dalam linguistik forensik meliputi fonetik dan fonologi ferensik, morfologi, sintaksis, semantik, pragmatik-sosio pragmatik, analisis wacana, gaya 
bahasa forensik, kecakapan berbahasa, dialektologi, dan kepengarangan. Dalam keperluan dalam tulisan ini, displin ilmu sintaksis, semantik, dan pragmatiklah yang digunakan sebagai teori untuk mengupas dan menunjukkan ekspresi penggunaan bahasa pada meme yang mengandung konten pelanggaran kriminal. Semantik merupakan ilmu bahasa yang memfokuskan kajian pada makna bahasa. Ullman (2014) semantik memiliki tiga aspek, yakni nama (name), makna (sense), dan benda (thing). Neme adalah bentuk fonetis suatu kata, bunyi-bunyi yang membentuk kata termasuk unsur-unsur akustik lainya seperti aksen. Selanjutnya sense disebut juga makna adalah infromasi yang dibawah oleh yang disampaikan kepada pendengar. Sementara thing merupakan unsur non bahasa yang dibicarakan.

Makna sendiri memiliki empat aspek sebagai mana disebut oleh Pateda (2010) aspek makna meliputi (1) Pengertian juga disebut dengan tema merupakan informasi lambang yang disampaikan kepada pendengar. Informasi tersebut bisa berupa ide, gagasa, pesan, perintah, permintaan, dan tawaran, (2) Rasa segala bentuk makna sebagai wujud dari persaan atas penilain (nilai rasa), (3) Nada berkaitan dengan bunyi suprasegmantal (jeda, intonasi, tekanan, dan pelafalan), serta (4) Maksud juga disebut dengan modus, yakni efek usaha yang ingin disampaikan oleh seorang untuk mendapat rekasi dari lawan bicara.

Untuk memaknai penggunaan unsur bahasa dalam meme, digunakan sebuah pendekatan semantik oprasional. Semantik operasional digunakan untuk menganalisis makna kata dalam operasionalnya atau penggunaanya. Dengan kalimat lain, pendekatan ini digunakan untuk melihat makna kata dalam konteks tuturan. Bridgman (Ullman, 2014) mengatakan makna sebenarnya dari sebuah kata harus ditemukan dengan mengamati apa yang dilakukan orang terhadap kata tersebut bukan mengamati apa yang dikatakannya tentang kata itu.

Selain analisis semantik digunakan juga analisis sintaksis. Sintaksis merupakan subdisiblin ilmu bahasa yang melihat kata, frasa, klausa sebagai satuan objek kajiannya. Dalam hal ini, pendekatan yang digunakan dalam pengkajian meme, yakni analisis sturktural unsur peran. Analisis dengan pendekatan ini berupaya mengindentifikasi peran pada tiap-tiap unsur sebuah klausa atau kalimat (Chaer, 2009). Lebih lanjut, Putrayasa (2007) analisis peran mengacu pada makna pengisi unsur-unsur fungsional kalimat. Makna unsur peran mengacu pada makna gramatikal/sintaksis. Dengan melihat pengisian unsur peran ini, dapatlah diketahui makna yang ada pada masing-masing unsur fungsional tersebut.

Dalam analisis unsur peran, sebelumnya perlu diketahui terlebih dahulu unsur fungsi dalam sebuah klausa atau kalimat. Ramlan (dalam Putrayasa, 2007), merincikan kemungkinan-kemungkinan makna unsur pengisi Subjek (S), yakni makna menyatakan pelaku, alat, sebab, hasil, tempat, penerima, pengalam, dikenal, dan terjumlah. Selanjutnya, makna pengisi predikat (P), yakni menyatakan perbuatan, keadaan, keberadaan, pengenal, jumlah, dan pemorelehan. Kemudian, makna unsur pengisis objek $(\mathrm{O})$, yakni menyatakan makna penderita, penerima, tempat, alat, dan hasil. Semenatara itu, kemngkinan makna pengisi unsur pelengkap (Pel), yakni menyatakan penderita, dan alat. Terkahir, makna unsur peran pengisi ketarangan (Ket), yakni makna menyatakan tempat, waktu, cara, penerima, peserta, alat, sebab, keseringa, perbandingan, dan perkecualian. Sementara Chaer ( 2009) kemungkinan makna unsur S dan O disatukan, yakni menyatakan makna pelaku, sasaran, hasil, penanggap, pengguna, penyerta, sumber, jangkauan, dan ukuran. Makna fungsional pengisi $\mathrm{P}$, yakni menyatakan makna proses, kejadian, keadaan, pemilikan, identitas, dan 
kuantitas. Selanjutnya, makna pengisi unsur fungsi K, yakni menyatakan makna, alat, tempat, waktu, asal, dan kemungkian atau keharusan.

Pemahaman suatu teks yang ada pada meme masih dirasakan belum lengkap jika hanya melihat makna dan sturutuk klausa/ kalimatnya saja. Interpretasi yang kuat/mapan terhadap penggunaan unsur-unsur bahasa pada sebuah teks meme patut juga perlu mempertimbangkan, tentang makna yang dimaksud orang, interpretasi dan peranggapan terhadap dieksis dan referensi yang digunakan, maksud atau tujuan tuturan, serta jenis-jenis tindakan (tindak tutur). Dalam kajian linguistik, hal tersebut dapat dilihat menggunakan kajian pragmatik. Nadar (2008) menjelaskan kajian pragmatik merupakan cabang linguistik yang mempelajari bahasa yang digunakan untuk berkomunikasi dalam situasi terntentu. Definesi lain, Yule (2006) studi tentang makna yang disampaikan oleh penutur (atau penulis) dan ditafsirikan oleh pendengar (atau pembaca). Dengan kalimat yang berbeda, pragmatik itu studi tentang maksud penutur. Untuk memahami maksud tuturan yang ada meme, seyogyanya perlu kita mengenal dieksis, refrensi, pranggapan dan jenis-jenis tindak tutur.

Dieksis merupakan bentuk lingustik yang dipakai untuk mewakali 'penunjukan' terhadap sesuatu diluar bahasa melalui bahasa (Yule, 2006). Lebih lanjut, Parker (1983) (dalam Nadar, 2008) sebuah kata dapat dikatakan dieksis apbila referenya berpindah-pindah atau berganti-ganti, tergantung pada saat dan tempat dituturkanya kata tersebut. Levinson (1983); Yule (2006) mengklasfikasi tiga jenis dieksis, (1) dieksis persona berhubungan dengan pemahaman mengenai peserta pertuturan dalam situasi pertuturan di mana tuturan tersebut dibuat. Atau dengan kalimat lain, dieksisi persona berhubungan dengan kata ganti orang. (2) dieksis tempat hubungan antara orang dan benda ditunjukkan dalam situasi tuturan, dan (3) dieksis waktu berhubungan dengan pemahaman titik acuan rentang waktu saat tutran dibuat.

Referensi terkait dengan tujuan (maksud) penutur (misalnya, untuk mengenali sesuau) dan keyakinan penutur terhadap lawan tutur dengan memahami maksud terhadap bentuk linguistik yang digunakan. Yule (2006) bentuk-bentuk linguistik merupakan ungakapanungkapan pengacuan, yang mungkin berupa nama diri, frasa nomina terntentu, frasa nomina tidak tentu, serta kata ganti orang. Penggunaan referensi dalam sebuah tuturan tentu dengan pertimbangan asumsi lawan tutur sudah memahami atau mengatahui apa yang dimaksud oleh penutur. Lebih lanjut Yule (2006) menjelaskan referensi dalam tuturan bukan merupakanhubungan antara arti dengan suatu kata atau frasa dengan suatu objek, melainkan referensi merupkan suatu tindakan sosial dimana penutur berasumsi bahwa kata atau frasa yang dipilih untuk mengenali suatu objek atau orang akan ditafsirkan sebagai yang dimaksudkan penutur. Referensi dibedakan menjadi tiga, yakni referensi anaforik, kataforik, dan anaforik zero (elipsis).

Selanjutnya, peranggapan atau disebut dengan presuposisi. Yule (2006) presuposisi merupakan sesuatu yang diasumsikan oleh penutur sebagai kejadian sebelummenghasilkan suatu tuturan. Levinson (1983) mengatakan bahwa presuposisi mengadung dua hal yakni keseusian atau kepuasan dan pemahaman bersama antara penutur dan lawan tutur.

Yang terakhir jenis tindak tutur. Tindak tutur merupakan tindakan-tindakan yang menghasilkan tuturan. Searle (1975) (dalam Wijana, 2022) mengkalsifikasikan jenis tindakan penutur dalam suatu tuturan, yakni tindak lokusi, ilokusi, dan perlokusi. Lebih lanjut, Yule 
(2006) dalam kepentingan kajian pragmatik tindakan ilokusi. Tindakan ilokusi adalah apa yang ingin dicapai oleh penutur pada waktu menuturkan sesuatu dan dapat merupakan tindakan menyatakan berjanji, minta maaf, mengancam, meramalkan, memerintah, meminta, dan lain sebagainya (Nadar, 2008). Jenis tindak tutur dapat dibedakan menjadi lima jenis, yakni deklarasi, refrenstatif, ekspresif, direktif, dan komisif (Yule, 2006). (1) Tindak tutur deklarasi adalah jenis tindak tutur yang menyatakan keputusan atau menamakan. (2) Tindak tutur refresentatif adalah jenis tindak tutur yang menyatakan apa dyakini penutur kasus atau bukan. Pernyataan suatu fakat, penegasan, kesimpulan, dan pendeskripsian. (3) Tindak tutur ekspresif ialah jenis tindak tutur yang menyatakan sesuatu yang dirasakan oleh penutur. Tindak tutur ini mencerminkan pernyataan berupa rasa kegembiraan, kesulitan, kesukaan, kebencian, kesenangan, atau kesengsaraan. (4) direktif ialah jenis tindak tutur yang dipakai oleh penutur untuk menyuruh orang lain melakukan sesuatu. Tindak tutur ini meliputi, perintah, pemesanan, permohonan, dan pemberian saran, dan (5) Komisif adalah jenis tindak tutur yang dipahami oleh penutur berupa janji, ancaman, dan penolakan.

\section{Metode}

Untuk keperluan analisis pembuktian bentuk ekspresi bahasa pada teks meme yang berpotensi masuk pada pelanggararan kriminal cyber crime, digunakan jenis penelitian kualitatif dengan pendekatan linguistik forensik. Dengan disain ini, unsur-unsur kebahasan seperti gramtika, semantik, serta unsur konteks bahasa akan dianalisis secara komperehensif untuk menunjukkan makna dan maksud bentuk bahasa yang digunakan pada meme. Data penelitian ini berupa teks pada meme yang mengandung konten pelanggaran hukum cyber (ceyber law). Data tersebut diambil dengan cara penelusuran secara online pada berbagai media sosial dan google. Selanjutnya data ini dianalisis dengan melakukan tahapan berikut: pengumpulan data pada meme, reduksi data, penyajian data, menganalisis data berdasarkan prinsip (semantic operasional, analisis unsur peran, dan prinsip pragmatik), simpulan dan verivikasi data.

\section{Hasil dan Pembahasan}

Penggunaan meme pada media masa merupakan suatu bentuk ekspresi penggunaan bahasa. Dari hasil penelitian yang dilakukan Listyorini (2017) tema yang biasa dituangkan dalam meme, yakni tema sosial, politik, hukum, dan HAM. Dalam penelitian ini, akan dibatasi meme dengan tema politik yang mengandung konten pelanggaran kriminal cyber crime. Data hanya dibatasi 4 data kasus yang dapat dijelaskan sebagai bentuk adanya potensi pelanggaran. 
a. Potensi kriminal cyeber crime berkonten penghinaan Pada Jokowi

Pertama pada meme yang menyerang pribadi Jokowi.

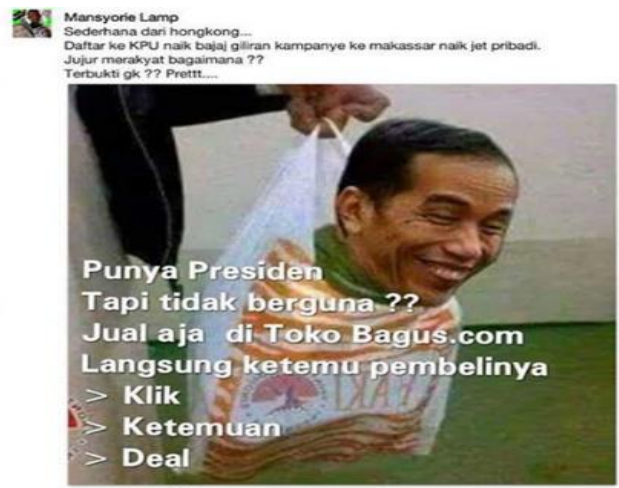

Gambar 1. Meme Jokowi

Pada meme tersebut terdapat tiga buah klausa, yakni (1) punya Presiden tapi tidak berguna??, (2) Jual saja di toko Bagus.com, (3) Langsung ketemu pembelinya > Klik > Ketemuan > Deal. Pada klausa pertama terdapat tiga unsur peran, yakni unsur punya miliki makna menunjukkan kata tanya, unsur presiden memiliki peran menunjukan pengindra, dan frasa tapi tidak berguna menunjukkan keadaan. Kemudian, pada klausa kedua terdapat dua unsur, yakni frasa jual saja yang memiliki peran menunjukkan tindakan, dan unsur frasa di toko Bagus.com menunjukkan unsur peran keterangan tempat. Selanjutnya, pada klausa ketiga memiliki tiga unsur, yakni unsur frasa langsung ketemu menunjukkan unsur peran tindakan, kata pembelinya menunjukkan unsur peran penyerta, dan unsur fara klik, ketemuan, deal menunjukkan unsur peran keterangan cara.

Pada klausa pertama ini terdapat kata presiden merujuk sebutan kepala Negara dalam hal ini Bapak Jokowi yang diperjelas dengan gambar pada meme. Kemudian frasa "tapi tidak berguna??" sama dengan tidak bermanfaat atau tidak mendatangkan keuntungan. Dalam konteks klausa ini presiden diangap seperti barang tidak berguna. Barang tidak berguna memiliki konotasi negatif. Selanjutnya, kalausa "jual saja di toko bagus.com". klausa ini merupakan anak dari klausa pertama. Frasa jual saja memiliki makna perintah untuk melakukan tindakan menjual. Barang yang akan dijual dalam konteks kalimat ini mengacu pada barang (presiden). Sementara frasa di toko bagus. Com merujuk kepada salah satu situs jual beli online. Klausa "Langsung ketemu pembelinya > Klik > Ketemuan > Deal" memiliki makna penjelasan cara melakukan teransaksi jual beli disitus tersebut.

Klausa pada meme yang diposting oleh akun inisial ML "Punya Presiden tapi tidak berguna?? Jual saja di toko Bagus.com Langsung ketemu pembelinya > Klik > Ketemuan > Deal" merupakan tindak ilokusi ekspresif yang menyatakan kebencian atau penghinaan. Konten penghinaan pada klausa ini ditunjukan dengan adanya penggunaan istilah atribut negara yakni kata presiden pada klausa "punya Presiden tapi tidak berguna??”. Pada kaluasa ini memiliki kata presiden memiliki unsur peran pengindra atau orang yang memiliki keadaan. Presiden yang dimaksudkan dalam meme ini sangat jelas mengacu kepada Bapak Jokowi yang dipertegas dengan penggunaan gambarnya. Sementara keadanya yang disebutkan yakni tidak berguna. Frasa tidak berguna memiliki makna konotasi negatif. Maknanya sama dengan 
tidak bermanfaat, atau tidak mendatangkan keuntungan. Selanjutnya, penggunaan kata presiden dalam meme ini disamakan dengan barang bekas yang dapat dijual kembali. Tentunya dengan adanya penggunaan istilah atribut negara seperti ini akan bermakna konotasi negatif.

Dengan demikian, konten meme tersebut jelas merupakan suatu bentuk ujaran kebencian. Yang secara jelas ditujukan kepada Presiden Jokowi. Wujud ujaran kebencian adanya pengunaan kata presiden dianggap sebagai barang bekas, dan menggap presiden tidak berguna. Meme tersebut diposting oleh akun inisial ML. Meme dapat diakses oleh semua orang sebagaimana dapat dikutip pada situs http://www.infospesial.net/52099/heboh-memejual-presiden-jokowi-pembuatnya-bisa-dipidana/.

Kemudian, data pada meme kedua. Meme masih bentuk penyerangan pribadi Jokowi.

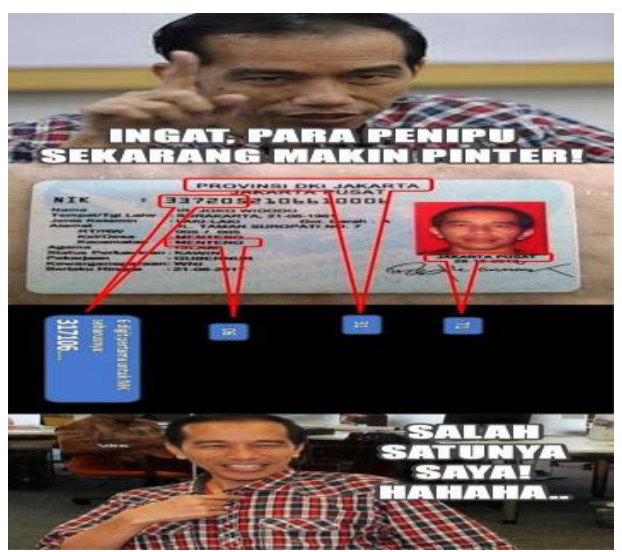

Gambar 2. Meme Jokowi

Pada meme ini terdapat dua klausa. Yakni klausa "Ingat, para penipu sekarang makin pinter!" pada klausa ini memiliki tiga buah konstituen berbentuk kata dan frasa. Kata ingat beperan sebagai ketarangan penegas, frasa para penipu sekarang beperan sebagai pengindra, dan frasa makin pinter berperan sebagai keadaan. Selanjutnya, klausa kedua "salah satunya saya" memiliki dua konstituen, yakni frasa salah satunya beperan sebagai jumlah dan saya berpesan sebagai terjumlah. Klausa kedua merupakan penjelas dari klausa kedua.

Makna unsur-unsur (kontituen) pada klausa "Ingat, para penipu sekarang makin pinter!" kata ingat secara referensial bermakna tidak lupa, timbul kembali dalam pikiran, menaruh perhatian, mempertimbangkan, hendak, dan hati-hati. Namun secara operasinal dalam konteks klausa ini bermakna suatu peringatan untuk hati-hati atau waspada. Frasa para penipu sekarang secara operasinal dalam klausa terebut memiliki makna julukan pada lebih dari satu orang yang memiliki sifat menipu. Dalam konteks meme tersebut, penipu mengacu pada orang yang melakukan pemalsuan indentitas kartu tanda penduduk. Tentunya, julukan penipu berkonotasi negatif. Sekanjutnya, frasa makin pinter makna suatu keadaan pandai atau cerdik yang meningkat namun digunakan dalam hal negatif. Selanjutnya, klausa kedua "salah satunya saya". Frasa salah satu bermakna mengacu kepada penipu yang disebutkan pada klausa pertama. Kata saya sendiri mengcu kepada Bapak Jokowi. Hal ini dapat dipertegs dengan gambar Jokowi menunjukkan diri pada meme tersebut. 
Klausa "ingat, para penipu sekarang makin pinter! Salah satunya saya." Merupakan tindak refresentatif penegasan yang mengandung konten penghinaan. Konten penghinaan pada klausa ini adanya penggunaan frasa para penipu dan penggunaan dieksis persona pertama tunggal saya. Telah dijelaskan secara semantik operasional penggunaan frasa para реnipu pada klausa tersebut memiliki makna julukan pada lebih dari satu orang yang memiliki sifat menipu atau tidak jujur. Dalam konteks meme tersebut, penipu mengacu pada orang yang melakukan pemalsuan indentitas kertu tanda penduduk. Penipu sendiri secara referensial memiliki makna perbuatan atau perkataan yang tidak jujur. Apabila kata ini diberikan sebagai julukan pada orang maka maknanya berkonotasi negatif. Sehingga masyarakat cendrung tidak akan menerima dirinya dijuluki dengan si penipu. Selanjutnya, pada klausa "salah satunya saya" adanya penggunaan dieksis persona saya yang mengacu pada klausa pertama, yakni para penipu. Artinya kata saya pada klausa juga memiliki sifat penipu sebagai mana yang dimaksud pada makna klausa pertama. Selain itu, dieksis saya juga mengacu pada orang yang ada di meme tersebut, yakni Jokowi. Artinya, sipembuat meme mengatakan Jokowi adalah salah orang yang termasuk penipu atau pemalsu kartu tanda penduduk.

Dari uraian tersebut, konten meme tersebut dapat dikatakan mengandung konten penghinaan dengan menggunakan istilah para penipu dan penggunaan kata saya. Penghinaan ini secara jelas ditujukan kepada Jokowi. Yang disebarkan oleh akun inisial NU. Meme ini dapat diakeses secara bebas oleh masyarakat pada situs https://www.kaskus.co.id/thread/53954616582b2ed30b8b472e/sentilan-sentilun-memejokowi-vs-prabowo/

b. Potensi kriminal Cyber crime berkonten penghinaan pada Prabowo

Meme pertama berisi konten ujaran kebencian atau penghinaan kepada Prabowo dapat dilihat pada gambar berikut.

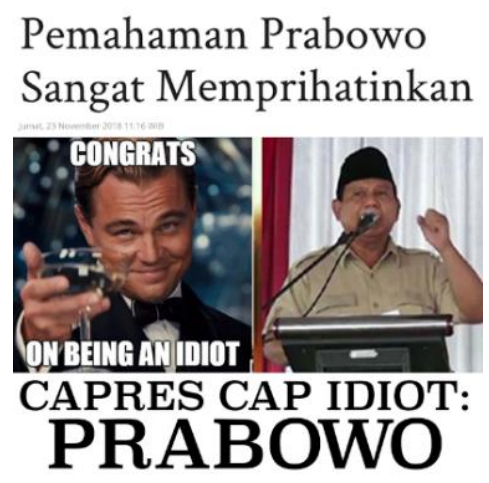

Gambar 3. Meme Jokowi

Pada meme ini memiliki tiga buah klausa, yakni (1) klausa Pemahaman Prabowo sangat memprihatinkan, (2) Congrats on being an idiot (3) Capres cap idiot: prabowo. Klausa pertama memiliki dua unsur peran, yakni frasa pemahaman prabowo memiliki unsur peran pengalam dan frasa sangat memperihatinkan memili unsur peran keadaan. Sementara pada klausa kedua memiliki tiga unsur, yakni congrats dengan unsur peran keterangan, on being unsur perannya bermakna mengacu pada makna pemeorelehan serta unsur an idiot unsur 
perannya sebagai hasil. Selanjutnya, unsur peran klausa ketiga memeliki dua unsur yakni,sebagai identitas pada frasa capres cap idiot dan sebagai pengenal pada frasa prabowo.

Makna semantik operasional pada frasa pemahaman Prabowo bermakna suatu cara pandang atau hasil memahami sesuatu (isu politik) yang dilakukan oleh Prabowo, selanjutnya frasa sangat memperihatikan bermakna menyedihkan dengan maksud mengiritik dengan nilai rasa meremehkan atau merendahkan.

Kemudian, klausa kedua Congrats on being an idiot. Merupakan suatu bentuk ungkapan selamat. Adanya penggunaan frasa an idiot pada klausa tersebut dengan makna referensial, yaitu menunjukkan tingkat kecerdasan daya pikir yang sangat rendah. Secara operasional an idiot pada frasa ini bermakna hasil usaha usaha yang dilakukan berupa daya pikir yang sangat rendah.

Pada klausa ketiga, "Capres cap idiot: prabowo". Makna operasinal frasa capres cap idiot pada klausa ini memiliki makna suatu identitas yang diberikan kepada Prabowo. Identitas tersebut adalah keadan idiot. Julukan atau cap idiot memiliki konotasi yang negatif jika diberikan kepada seorang.

Ketiga klausa yang terdapat pada meme tersebut dapat dikatakan sebagai bentuk tindak ilokusi refrenstatif yang menyatakan kebencian atau penghinaan pada seseorang. Bentuk penginaan adanya penggunaan kata idiot, capres cap idiot, dan ditujukan kepada Prabowo. Berdasarkan analisis semantik operasional dalam penggunaan kata idiot pada klausa "Congrats on being an idiot" merupakan suatu usaha yang dilakukan oleh Prabowo. Sementara usaha tersebut berkonotasi negatif. Begitu juga halnya dengan penggunaan frasa capre cap idot pada klausa "Capres cap idiot: prabowo" memiliki makna pemberian identitas yang berkonotasi negatif pada seseorang, yakni cap atau julukan capres idiot. Dari ketiga klausa tersebut berupa penilaian atau pengeritkan yang bersifat merendahkan, ucapan dengan ungkapan penghinaan, dan pemberian julukan negatif, secara jelas ditujukan kepada Prabowo.

Oleh karana itu, dapat disimpulkan bahwa meme tersebut dapat dikatakan memiliki muatan penghinaan yang ditujukan kepada Prabowo. Meme ini dapat diakeses secara bebas oleh masyarakat pada situs http://www.politikpanas.com/2018/11/prabowo-berbicarablunder.html. Yang diposting pada tanggal 23 Novemver 2018.

Kemudian, meme yang kedua juga perpotensi melanggara kriminal cyber crime yang berkonten penghinan pada Prabowo dapat dilihat pada gambar berikut.

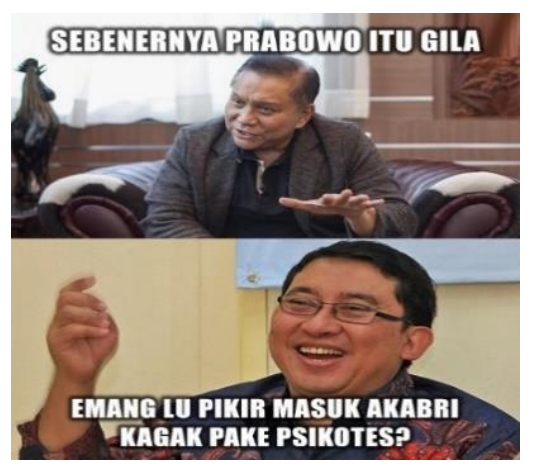

Gambar 4. Meme Prabowo 
Meme ini terdapat dua buah klausa, yakni "Sebenarnya prabowo itu gila" dan klausa "Emang lu pikir masuk AKABRI kaga peke psikotes?". Unsur pengisi peran pada kata sebenarnya adalah keterangan pengas, frasa prabowo itu unsur peranya menyatakan pengindra, dan kata gila dengan unsur perannya menyatakan keadaan. Kemudian, pada klausa kedua terdapat unsr peran pemarkaha introgatif, pelaku, proses, sasaran, dan penegas.

\section{Simpulan}

Berdasarkan analisis dengan pendekatan linguistik forensik terhadap keempat meme tersebut berpotensi melanggar kriminal cyeber cream. Potensi pelanggarannya, yakni penghinaan terhadap kerhormatan/ nama baik orang lain. Konten penghinaan ditunjukkan dengan adanya penggunaan bentuk lingual (kata, frasa, klausa) seperti penggunaan klausa presiden tidak beguna, penggunaan kata penipu, gila, dan idiot. Bentuk lingual seperti ini memiliki makna berkonotasi negatif atau tidak baik. Yang menyebabkan adanya rasa pengihinaan pada orang yang dituju. Selain dari pada itu, keempat meme ini disebarluaskan dengan unsur kesengajaan atau dapat dapat dikatakan bahwa penyebarnya mengerti terhadap konsekuensi yang dilakukan.

Dalam KUHP, telah diatur pada Bab XVI pasal 310 sampai pasal pasal 321 tentang pidana pelanggaran penghinaan. Selanjutnya, perlu juga dilihat dengan menggunakan UUITE pasal 45 ayat 3 yang berbunyi "Setiap Orang yang dengan sengaja dan tanpa hak mendistribusikan dan/atau mentransmisikan dan/atau membuat dapat diaksesnya Informasi Elektronik dan/atau Dokumen Elektronik yang memiliki muatan penghinaan dan/atau pencemaran nama baik sebagaimana dimaksud dalam Pasal 27 ayat (3) dipidana dengan pidana penjara paling lama 4 (empat) tahun dan/atau denda paling banyak Rp750.000.000,00 (tujuh ratus lima puluh juta rupiah)"

\section{Daftar Pustaka}

Bauckhage, C. (2011). "Insight into Internet Memes". Proceedings of the Fifth International AAAI Conferenceon Weblogs and Social Media. Diunduhdarihttp://www.aaai.org/ocs/index.php/ICWSM/ICWSM11/paper/viewFile/2 $757 / 3304$.

Chaer, A. (2009). Sintaksis Bahasa Indonesia (pendekatan proses) Jakarta: Rineka Cipta.

Coulthard, M. dan Alison, J (Eds.). (2010). An Introduction to Forensic Linguistics: Language in Evidence. New York: Rouledge.

http://www.politikpanas.com/2018/11/prabowo-berbicara-blunder.html. https://tirto.id/jerat-uu-ite-banyak-dipakai-oleh-pejabat-negara-c7sk, diakes 2019. https://www.kaskus.co.id/thread/53954616582b2ed30b8b472e/sentilan-sentilun-memejokowi-vs-prabowo/

https://www.kaskus.co.id/thread/53954616582b2ed30b8b472e/sentilan-sentilun-memejokowi-vs-prabowo/

Kitab Undang-Undang Hukum Pidana (KUHP). (Wetboek Van Strafrecht, Staatsblad 1915 No. 732).

Listiorini, A. (2017). Wacana humor dalam meme di media online sebagai potret kehidupan sebagian masyarakat Indonesia. LITERA, 16(1). 
Nadar, F. X. (2009). Pragmatik \& penelitian pragmatik. Graha Ilmu.

Olsson, J. (2008). Forensic Linguistics. New York : Continuum.

Putrayasa, I. B., (2007). Analisis Kalimat: Kategori, Fungsi, dan Peran. Bandung: Refika Aditama.

Subyantoro, S. (2019). Linguistik Forensik: Sumbangsih Kajian Bahasa dalam Penegakan HUKUM. ADIL Indonesia Journal, 1(1).

Subyantoro. (2017). Linguistik Forensik: Sebuah Pengantar. Semarang: Farishma Indonesia.

Tianotak, N. (2011). Urgensi cyberlaw di indonesia dalam rangka penangan cybercrime disektor perbanka. Jurnal Sasi, 17(4).

Ullman, S. (2012). Semantics, An Introduction to the Sceince Of Meaning. Oxford: Basil Blachwell. Di adaptasi oleh Sumarsono. Pengantar Semantik. Yogyakarta: Pustaka Pelajar.

Undang-Undang Informasi dan Transaksi Elektronik (UU ITE) Nomor 11 Tahun 2008.

Wijana, I. D. P., \& Rohmadi, M. (2010). Analisis wacana pragmatik: Kajian teori dan analisis. Surakarta: Yuma Pustaka.

Yule, G. (2006). Pragmatics. England: Oxford University Press (terjemahan dalam bahasa Indonesia oleh Indah Fajar Wahyuni, dengan judul Pragmatik). Yogyakarta: Pustaka Pelajar. 